\title{
Neck Dissection Indications in Lower Lip Squamous Cell Carcinoma Cases: Our Experience in 96 Cases
}

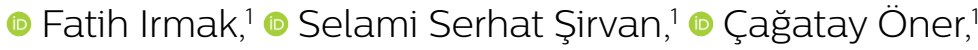

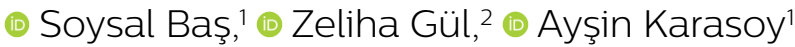

\section{'Department of Plastic, Reconstructive and Aesthetic Surgery, University of Health Sciences, Sişli Hamidiye Etfal Training and Research Hospital, Istanbul, Turkey 2Department of Plastic Reconstructive and Aesthetic Surgery, Nizip State Hospital, Gaziantep, Turkey \\ Submitted: 11.11.2018 Accepted: 04.02.2019 \\ Correspondence: Fatih Irmak Şişli Hamidiye Etfal Eğitim ve Araştırma Hastanesi, Plastik, Rekonstrüktif ve Estetik Cerrahi Kliniği, Şişli, İstanbul, Turkey \\ E-mail:dr.fatihirmak@gmail.com \\ Keywords: Lower lip tumors; neck dissection; squamous cell carcinoma.}

\begin{abstract}
Objective: Squamous cell carcinoma (SCC) is the most common lip carcinoma and nodal status is the single most important prognostic factor. Though surgery is the first choice of treatment in early-stage cases, elective neck dissection to treat an eventual occult metastasis is still a matter of discussion.
\end{abstract}

Methods: A total of 96 patients with lower lip SCC who were operated on in a single clinic between January 2005 and July 2017 were included in this study. Patients who did and did not undergo elective neck dissection after tumor resection according to risk and nodal status were studied in terms of age, gender, tumor size, and neck dissection type.

Results: Among 96 patients, 74 were classified as TI-2N0 according to the American Joint Committee on Cancer staging system, and 30 underwent elective neck dissection. Among these 30 patients, 6 were diagnosed with metastasis. A total of 51 of the 96 members of the study group underwent elective supraomohyoid neck dissection. In all, 23 patients were diagnosed with metastasis.

Conclusion: Lower lip SCC is a cancer with a relatively good prognosis, but regional lymph node metastasis decreases the survival rate substantially. In selected cases, staging the tumor via supraomohyoid neck dissection or sentinel lymph node biopsy is adequate to detect occult metastasis and prevent late lymph node metastasis.

\section{INTRODUCTION}

Lower lip carcinoma is the most common form of lip cancer $(80 \%)$ and represents approximately $30 \%$ of all oral carcinomas. $^{[1,2]}$ Most cases of lower lip cancer are cutaneous squamous cell carcinoma (cSCC), the second-most frequently diagnosed malignant skin cancer after basal cell carcinoma. ${ }^{[3]}$ Though there are many risk factors, including older age, male gender, human papilloma virus, immunosuppression, fair skin, or tobacco smoking, the most important risk factor is cumulative ultraviolet exposure. ${ }^{[4]}$

Lower lip SCC spreads first to the submandibular or submental lymph nodes. ${ }^{[5,6]}$ Though surgical resection is the current treatment of choice for early stage lower lip SCC, the practice of elective lymph node dissection in high-risk patients or cases classified clinically as NO according to the American Joint Committee on Cancer (AJCC) staging system with no locally advanced disease is still a contro- versial subject. ${ }^{[7]}$ Some authors consider the practice of elective lymph node dissection in clinically determined N0 cases complementary and necessary, ${ }^{[6,8]}$ while others consider the practice of neck dissection in patients who have no clinical (physical examination, radiological evaluation) evidence of a pathological lymph node to be excessive. ${ }^{[9,10]}$ In this context, patients operated on in a single clinic between January 2005 and July 2017 with a lower lip SCC diagnosis were analyzed retrospectively and an analysis was performed to evaluate the approach to lower lip SCC, neck dissection indications, and the contribution of neck dissection to the relative survival rate.

\section{MATERIAL AND METHODS}

In this study, the data of 96 lower lip SCC patients who were admitted to the clinic and followed-up between January 2005 and July 2017 were analyzed. The patients were 
classified according to age, gender, tumor size, pathological type, and the type of neck dissection. The study was conducted according to the principles of the Helsinki Declaration. Patients who were referred to the clinic after primary tumor excision, wide excision, or local recurrence were not included in this study. The diagnoses of patients included in this study were confirmed with a preoperative punch or incisional biopsy. The patients were staged according to the AJCC staging system. ${ }^{\left[{ }^{[1]}\right.}$ Regional or distant metastasis status was evaluated with ultrasound imaging, computed tomography (CT), or positron emission tomography-CT scan, according to the tumor stage.

\section{Approach to lymph nodes}

A wedge excision was performed followed by a primary repair when the defect size was less than one-third of the lower lip. The surgical resection was followed by a one-sided or bilateral local flap reconstruction for defects beyond one-third of the lower lip. In cases where a freetissue transfer was required, the defect was temporarily closed and the reconstruction was postponed until safe margins were confirmed with a pathology report. Defect reconstruction will not be detailed in this article. Supraomohyoid neck dissection (SOHLND; lymphadenectomy of level I-II-III lymph nodes) was performed in clinically or radiologically determined lymph node-negative TI and T2 stage patients if the invasion depth was $>2 \mathrm{~mm}$, in immunosuppressed patients, in cases of a poorly differentiated tumor, and in cases with perineural invasion. SOHLND was performed simultaneously in T3-4N0 cases. The dissection was performed bilaterally in cases when the tumor was centrally located. A functional (or type 3 modified-radical) neck dissection, a lymphadenectomy of level I through $\mathrm{V}$ lymph nodes sparing the sternocleidomastoid muscle (SCM), internal jugular vein (IJV), and spinal accessory nerve $(\mathrm{CN} X \mathrm{X})$ or a modified-radical neck dissection (MRND), a lymphadenectomy of level I through $\checkmark$ lymph nodes sparing either I, 2, or all of the following structures: SCM, IJV, CN XI was performed. In clinically positive cervical lymph node cases, a functional dissection or MRDN was preferred. Patients with a pathology report of metastasis in the neck dissection material were referred to the radiation oncology department due to the potential need for adjuvant radiotherapy. Patients were followed-up every 3 months for 2 years and then every 6 months the following year and annually after the fourth year.

\section{RESULTS}

Of the 96 patients in this study, 82 were male (85\%) and 14 were female (15\%). The youngest patient was 22 years old and the oldest was 87 years of age; the mean age was 59.4 years. The mean length of the follow-up period was 68 months, with a range of 12 to 129 months. In total, an elective (supraomohyoid) neck dissection was performed on $5 \mathrm{I}$ of the 96 patients (Table I). A metastasis was detected in the pathology material of 23 patients in this group.
Table I. Treatment modalities according to the TNM classification of malignant tumors

\begin{tabular}{lll}
\hline TNM & & Treatment modality \\
\hline TINO & & \\
High-risk factor: & - & - \\
& + & SOHLND \\
& ++ & SOHLND/Functional \\
TINI & + & \\
High-risk factor: & + & SOHLND \\
T2N0 & ++ & Functional \\
High-risk factor: & + & \\
& ++ & SOHLND \\
& +++ & SOHLND/Functional \\
T2NI-2 & & MR \\
High-risk factor: & ++ & \\
T3NO & +++ & \\
High-risk factor: & + & Functional \\
T3NI-2 & ++ & MR \\
T4NX & & Functional \\
\hline
\end{tabular}

MR: Modified radical lymph node dissection; SOHLND: Supraomohyoid lymph node dissection.

Table 2. High-risk factors for cutaneous squamous cell carcinoma

High-risk factors for cSCC according to the American Joint Committee on Cancer

\begin{tabular}{lc}
\hline Tumor diameter & $>2 \mathrm{~cm}$ \\
Invasion depth & $>2 \mathrm{~mm}$ \\
Perineural invasion & + \\
Poor differentiation & + \\
Immunosuppression & + \\
\hline
\end{tabular}

cSCC: Cutaneous squamous cell carcinoma

A total of 74 patients with TI-2N0 staging were clinically and radiologically node-negative. However, we performed supraomohyoid or functional neck dissection to 30 cases due to the presence of I or more high-risk factors. These high-risk factors are summarized in Table 2. Among these 30 patients, a lymph node metastasis was detected in 6 cases $(6 \%$ in total, $20 \%$ of patients undergoing neck dissection). Analysis of the patients with a positive lymph node finding after dissection revealed that 5 patients of 6 had 2 or more high-risk factors, and I patient had only I high-risk factor (poorly differentiated). Among the 57 TI stage (tumor size $<2 \mathrm{~cm}$ ) patients, independent of $N$ stage, 22 had a neck dissection and 10 were diagnosed with metastasis (17.5\%). Among all of the T2 stage patients (tumor size $>2 \mathrm{~cm}$, or any size with more than 2 high-risk factors), a total of 30 patients, 2I had a neck 
dissection and 9 were diagnosed with metastasis (30\%). Six of 7 T3 stage patients had a neck dissection. One patient did not elect to have the dissection and was referred to the radiation oncology department. Among the 6 neck dissection patients, 3 were diagnosed with lymph node metastasis (50\%). A MRND was performed for 2 stage T4 patients. The pathology department reported lymph node metastasis in both biopsies (100\%). In a mean follow-up period of 5.5 years, regional metastatic lymph node recurrence was observed in 2 patients of 96 (approximately $2 \%)$. A retrospective examination of these 2 cases with recurrence revealed that I patient was at T2N0 stage with I high-risk factor and clinically and radiologically negative lymph node status and had a SOHLND at the time of excision. The recurrence appeared at the postoperative third year. The other patient was at T2N0 stage with 2 high-risk factors and was advised to have a neck dissection after wide tumor excision but the patient did not give consent. Strict follow-up was performed and recurrence occurred $21 / 2$ years after the operation.

A metastasectomy was performed for patients according to the decision of the multidisciplinary tumor council of the hospital. Patients who had a positive metastatic lymph node(s) in their supraomohyoid neck dissection pathology material underwent a complementary MRND, if possible. Those who had positive metastatic lymph node(s) in their functional or MRND pathology material were referred to the radiation oncology department.

A wedge excision followed by a primary closure was performed for $4 \mathrm{I}$ patients among 96 . The resections were full-thickness with a minimum safe margin of $0.5 \mathrm{~cm}$ for TI cases and with a minimum safe margin of $1 \mathrm{~cm}$ for T2-3-4 cases.

\section{DISCUSSION}

Lower lip SCC is known to have a relatively good prognosis; however, it is also known that lower lip SCC cases may be more invasive and metastatic compared with other head and neck cutaneous SCC cases. ${ }^{[12]}$

Lymph node metastasis in lower lip carcinomas, which are often diagnosed early due to their anatomical localization, considerably lowers the survival rate (approximately 50\%), according to many authors. ${ }^{[6]}$ There is a consensus on the necessity of functional (Bocca) neck dissection or MRND to treat level I-V nodes in clinically positive cases independent of $\mathrm{T}$ stage, as is suggested by the National Comprehensive Cancer Network guidelines. ${ }^{[13]}$ However, that is not true for clinically negative $\mathrm{NO}$ cases. The results of I study that suggested elective supraomohyoid neck dissection in these cases found an approximate rate of occult metastasis of $20 \% .{ }^{[6]}$ We calculated a rate of $6 \%$ in our study.

Ciloglu et al. ${ }^{[14]}$ did not suggest elective lymph node dissection in Grade I, clinically negative tumors. In our study, neck dissection was performed independent of the $N$ stage in 22 of $57 \mathrm{TI}$ staged patients and 10 were diag- nosed with metastasis. Neck dissection should be kept in mind in high-risk TI tumors.

The common understanding concerning elective neck dissection in head and neck cancers is that there is a $15 \%$ to $20 \%$ rate of regional metastasis. ${ }^{[15-17]}$ Califano et al. ${ }^{[18]}$ argue that capsule rupture and tumor size are the most important parameters regarding the development of cervical metastasis. It is known that tumors surrounded by a large lymphocyte band and well-differentiated carcinomas develop less cervical metastasis. ${ }^{[16,19]}$ The other high risk SCC characteristics determined by the AJCC are tumor depth ( $2 \mathrm{~mm}$ and beyond), perineural invasion, and immunosuppression. ${ }^{[1,20]}$ It has been shown that lesions in this high-risk group tend to develop more recurrence and metastasis. Supraomohyoid neck dissection has less comorbidity than MRND aesthetically and functionally. The main reasons are the preservation of neck volume and the functionality of shoulder. ${ }^{[21]}$ It has been reported that $5 \%$ to $15 \%$ of N0 lower lip SCC patients treated only with primary tumor resection have developed late cervical metastasis. ${ }^{[22,23]}$

In a study by Koc et al.," ${ }^{[24]}$ prophylactic neck dissection was performed for all patients without lymph node metastasis. They concluded that supraomohyoid lymph node dissection should be performed for N0 tumors to decrease the risk of neck node metastasis.

In the literature, there is no consensus concerning the approach to be used for a clinically negative neck node in patients with early grade lip tumors and the reported incidence of neck node metastases has ranged from $0 \%$ to $15 \%$ for $\mathrm{TI}$ tumors and II \% to $35 \%$ for T2 tumors. ${ }^{[25]}$

Occult metastasis in the early stage is often the reason for late cervical metastasis in these cases. As De Visscher et al. ${ }^{[26]}$ and Hosal et al. ${ }^{[27]}$ confirmed that the existence of late cervical metastasis is very resistant to treatment and results mostly in the patient's death in a I-year period. Though sentinel lymph node biopsy (SLNB) is currently a standard therapy in staging breast cancer and malignant melanoma, this is not the case for head and neck SCC. The potential benefit of SLNB in lower lip SCC cases is being researched in many centers. Sensitivity and negative predictive values have been compared in the use of metastasis detection, and it has been found that SLNB is more predictive than radiological studies but less predictive than selective lymph node dissection. ${ }^{[28-31]}$

\section{CONCLUSION}

The results of this study demonstrated that lower lip SCC has a good prognosis among other head and neck cancers with early surgical treatment; however, late cervical metastasis is far from negligible and decreases the survival rate considerably. Therefore, our results support the necessity of performing elective supraomohyoid neck dissection in selected NOTI-2 lower lip SCC cases due to the risk for recurrence and metastasis. It is also evident 
that SLNB, which is an effective and less comorbid way to assess lymph node status, could be a good option for patients who do not accept a selective neck dissection.

Based on the results of this study, the presence of a highrisk factor is one of the important parameters that should inform the decision about performing lymph node dissection with early stage lower lip carcinoma cases. We advocate at least a prophylactic SOHLND in patients who have high-risk factor(s) with cSCC of the lower lip with a clinically NO neck and we advocate a SOHLND or functional/MR lymph node dissection for clinically $\mathrm{N}$-positive necks, according to the $T$ stage and number of high-risk factors.

Ethics Committee Approval

Retrospective study.

Peer-review

Internally peer-reviewed.

Authorship Contributions

Concept: F.I., A.K., Ç.Ö.; Design: F.I., Ç.Ö., S.S.Ş.; Data collection \&/or processing: F.I., S.B., S.S.Ş., Z.G.; Analysis and/ or interpretation: F.I., A.K.; Literature search: F.I., S.S.Ş.; Writing: F.I., Ç.Ö.; Critical review: F.I., S.B., S.S.Ş.

Conflict of Interest

None declared.

\section{REFERENCES}

1. Regezi JA, Sciubba JJ, Jordan RCK. Ulcerative conditions. In: Oral Pathology Clinical Pathologic Correlations, editors. 7th edition. St Louis: Saunders; 2016. p. 23-79.

2. Czerninski R, Zini A, Sgan-Cohen HD. Lip cancer: incidence, trends, histology and survival: 1970-2006. Br J Dermatol 2010;162:1103-9.

3. Hoffman HT, Karnell LH, Funk GF, Robinson RA, Menck HR. The National Cancer Data Base report on cancer of the head and neck. Arch Otolaryngol Head Neck Surg 1998;124:951-62. [CrossRef]

4. Wiser I, Scope A, Azriel D, Zloczower E, Carmel NN, Shalom A. Head and neck cutaneous squamous cell carcinoma clinicopathological risk factors according to age and gender: a population-based study. Isr Med Assoc J 2016;18:275-8.

5. Zitsch RP 3rd, Park CW, Renner GJ, Rea JL. Outcome analysis for lip carcinoma. Otolaryngol Head Neck Surg 1995;113:589-96.

6. Bucur A, Stefanescu L. Management of patients with squamous cell carcinoma of the lower lip and N0-neck. J Craniomaxillofac Surg 2004;32:16-8. [CrossRef]

7. Zitsch RP, Lee BW Smith RB. Cervical lymph node metastases and squamous cell carcinoma of the lip. Head Neck 1999;21:447-53.

8. Yilmaz S, Ercocen AR. Is elective neck dissection in T1-2, N0 patients with lower lip cancer necessary? Ann Plast Surg 2009;62:3813. [CrossRef]

9. Babington S, Veness MJ, Cakir B, Gebski VJ, Morgan GJ. Squamous cell carcinoma of the lip: is there a role for adjuvant radiotherapy in improving local control following incomplete or inadequate excision? ANZ J Surg 2003;73:621-5. [CrossRef]

10. de Visscher JG, Botke G, Schakenraad JA, van der Waal I. A comparison of results after radiotherapy and surgery for stage I squamous cell carcinoma of the lower lip. Head Neck 1999;21:526-30. [CrossRef]

11. Edge SB, Byrd DR, Compton CC, Fritz AG, Greene FL, Trotti A.
AJCC cancer staging manual. 7th edition. New York: Springer; 2010. 12. Silistreli OK, Ayhan M, Kilic M, Gorgu M, Oztan Y, Sisman N. The Role and Criterias of NeckDissection for the Treatment of Epidermoid Carcinoma of the Head and Neck Region: 5 Years Experience. Turk Plast Rekontr Est Cer Derg 2003;11:172-6.

13. National Comprehensive Cancer Network (NCCN). Squamous cell skin cancer (Version 2.2018). Available at: https://www.nccn.org/ professionals/physician_gls/pdf/squamous.pdf. Accessed February 15, 2019.

14. Ciloglu NS, Yesiladali KG, Zeytin K. Lower Lip Cancer Treatment and Reconstruction Options: A retrospective evaluation of $51 \mathrm{pa}$ tients. Haydarpaşa Numune Medical Journal 2013;53:136-40.

15. Kuscu O, Bajin MD, Süslü N, Hoşal AS. The role of suprahyoid neck dissection in the treatment of squamous cell carcinoma of the lower lip: 50 years' experience at a Tertiary Centre. J Craniomaxillofac Surg 2016;44:1404-7. [CrossRef]

16. Shah JP, Patel SG, Singh B. Lips. In: Shah JP, Patel SG, Singh B, editors. Jatin Shah's Head and Neck Surgery and Oncology. 4th edition. Philadelphia: Elsevier; 2012. p. 204.

17. Teichgraeber JF, Clairmont AA. The incidence of occult metastases for cancer of the oral tongue and floor of the mouth: treatment rationale. Head Neck Surg 1984;7:15-21. [CrossRef]

18. Califano L, Zupi A, Massari PS, Giardino C. Lymph-node metastasis in squamous cell carcinoma of the lip. A retrospective analysis of 105 cases. Int J Oral Maxillofac Surg 1994;23:351-5. [CrossRef]

19. Cantù G, Chiesa F, Molinari R. Risultati Dellaterapiadella Diffusione Linfatica del carcinoma del labbro e della commessura labiale. Nuovo Arch Ital Otol 1977;5:483-8.

20. Connolly KL, Nehal KS, Disa JJ. Evidence-Based Medicine: Cutaneous Facial Malignancies: Non Melanoma Skin Cancer. Plast Reconstr Surg 2017;139:181e-190e. [CrossRef]

21. Gooris PJ, Vermey A, de Visscher JG, Burlage FR, Roodenburg JL. Supraomohyoid neck dissection in the management of cervical lymph node metastases of squamous cell carcinoma of the lowerlip. Head Neck 2002:24;678-83. [CrossRef]

22. Kutluhan A, Kiriş M, Kaya Z, Kisli E, Yurttaş V, Içli M, et al. Squamous cell carcinoma of the lower lip and supra-omohyoid neck dissection. Acta Chir Belg 2003;103:304-8. [CrossRef]

23. Sharma PK, Schuller DE, Baker SR. Malignant neoplasms of the oral cavity. In: Cummings CW, Frederickson JM, Harker LA, Krause CJ, Schuller DE, editors. Otolaryngology Head and Neck Surgery. St. Louis: Mosby; 1998, p. 1143-4.

24. Koc AK, Acipayam H, Kocak HE, Alakhras WM, Yegin Y, Kayhan FT. Our Clinical Approach to Lip Cancer; Surgery and Reconstruction Principles. Okmeydanı Tip Dergisi 2017;33:139-43.

25. Demir D, Genc S, Guven M, Yilmaz MS, Kara A. Approachment to Neck in Early Stage Lip Cancers. Sakarya Med J 2017;7:184-7.

26. de Visscher JG, van der Elsakker K, Grond AJ, van der Wal JE, van der Waal I. Surgical treatment of squamous cell carcinoma of the lower lip: evaluation of long-term results and prognostic factors-a retrospective analysis of 184 patients. J Oral Maxillofac Surg 1998;56:814-20. [CrossRef]

27. Hosal IN, Onerci M, Kaya S, Turan E. Squamous cell carcinoma of the lower lip. Am J Otolaryngol 1992;13:363-5. [CrossRef]

28. Sollamo EM, Ilmonen SK, Virolainen MS, Suominen SH. Sentinel lymph node biopsy in cN0 squamous cell carcinoma of the lip: A retrospective study. Head Neck 2016;38:E1375-80. [CrossRef]

29. Gershenwald JE, Ross MI. Sentinel-lymph-node biopsy for cutaneous melanoma. N Engl J Med 2011;364:1738-45. [CrossRef]

30. Benson JR, della Rovere GQ; Axilla Management Consensus Group. Management of the axilla in women with breast cancer. Lancet Oncol 2007;8:331-48. [CrossRef] 
31. Alkureishi LW, Ross GL, Shoaib T, Soutar DS, Robertson AG, Thompson R, et al. Sentinel node biopsy in head and neck squamous cell cancer: 5-year follow-up of a European multicenter trial. Ann Surg Oncol 2010;17:2459-64. [CrossRef]

\section{Alt Dudak Skuamöz Hücreli Karsinom Olgularında Boyun Diseksiyonu Endikasyonları: 96 Olgu Üzerindeki Klinik Tecrübelerimiz}

Amaç: Lenf nodu tutulumu, alt dudak skuamöz hücreli karsinom olgularındaki en önemli prognostik faktördür. Erken evrelerde cerrahi ilk seçenek olmasına rağmen, okkült metastazları saptamak için de olsa elektif lenf nodu diseksiyonu yapılması hala tartışma konusudur.

Gereç ve Yöntem: Bu çalışmaya Ocak 2005 ve Temmuz 2017 yılları arasında ameliyat edilen 96 alt dudak skuamöz hücreli karsinom olgusu alındı. Tümör rezeksiyonu sonrası, risk ve lenf nodu tutulumuna göre boyun diseksiyonu yapılmış olan veya yapılmamış olan olgular; yaş, cinsiyet, tümör büyüklüğü ve yapılan boyun diseksiyonu tipine göre incelendi.

Bulgular: Ameliyat edilenlerde 74 olgu TI-2N0 evresinde idi ve bunların 30'una elektif lenf nodu diseksiyonu uygulandı ve bu 30 hastanın altısında metastaz saptandı. Olguların 5 l'ine elektif lenf nodu diseksiyonu uygulandı ve bunların 23'ünde metastaz saptandı.

Sonuç: Alt dudak skuamöz hücreli karsinomları relatif olarak iyi prognoza sahip olmasına rağmen, rejyonel lenf nodu metastazı sağkalım oranını belirgin şekilde düşürür. Okkült metastazları saptamak ve geç dönem lenf nodu metastazlarını önlemek için, seçilmiş olgularda sentinel lenf nodu biyopsisi ya da supraomohiyoid lenf nodu diseksiyonları akılda tutulması gereken işlemlerdir.

Anahtar Sözcükler: Alt dudak tümörleri, boyun disseksiyonu, skuamöz hücreli karsinom. 